\title{
The Living Language Laboratory
}

Herbert Hochhauser

During the second half of this century foreign language study in the United States has not enjoyed much success. There was a short renaissance right after the ascent of Sputnik. Generally the study of foreign languages has not meant a mastery of the tongue but a fulfilment of requirements. Once the course-hour requirement had been reached it was time to burn the dictionary. The attitude was: Let the other Nationals learn English and leave us in our monolingual ignorance.

If an American did venture south of the border the local merchant did speak enough English to send the Gringo back home with enough native souveniers for the entire family. One could find Englishspeaking personnel at all of Europe's major tourist attractions. Until very recently Americans, with the exception of those engaged in foreign commerce, were never forced to communicate in a foreign tongue. When you are selling you sell in the consumer's tongue. The buyer can force the seller to communicate with him in the buyer's native tongue. This type of situation is new to the domestic merchant. In a specific area of the United States Americans are beginning to realize that learning a second language is a means for economic survival.

The area in question is Miami, Florida. A census taken in Spring 1975 indicated that $52 \%$ of the population is Cuban. English is no longer the only language of this major American city. It now must share this distinction with Spanish. In the field of language study economics has been able to do that which educators were unable to do.

Ever since the Cuban Revolution there has been a steady influx of Cubans to the United States. The majority of them settled in Miami. Miami was in close proximity to their former home, climatic conditions were similar, and since many entertaired an eventual return to a nonCastro Cuba, it seemed logical to settle there. Today Cubans represent the area's largest single ethnic group, far outnumbering Jamaicans, Bahamians, and other Latins.

These immigrants are different than the masses that arrived from Europe at the turn of the century. A large percentage of these Cubans are highly skilled professionals. The skills, which they attained in Cuba, were saleable in Miami. Many of these people had their money deposited in Miami banks during the Batista regime. These were certainly not the pennyless, unskilled, and uneducated refugees that were processed at Ellis Island. The majority of Cubans were hard- 


\section{Living Lab}

working individuals, whose ambitions soon gained them a position in this society which was similar to the one they had left behind.

Their large number, coupled with their economic impact had a remarkable effect upon life in Miami. There is no desire among the Cubans to loose their identity and to disappear into the proverbial melting pot. There is no great rush to Americanize their names or to replace English as their main language.

There are Cuban-owned banks, radio and television stations. Several radio stations broadcast exclusively in Spanish. The C.B.S. affiliated FM station provides a Spanish soundtrack for the C.B.S. Television Evening News. By turning down the television audio and tuning in the FM station one can listen to Walter Cronkite, Eric Severeid, and Dan Rather in Spanish. Some television stations bring American programs with Spanish audio. To a mid-westerner it is at first a cultural shock to hear Eliot Ness speak Spanish. English language radio and television stations will broadcast their commercials in both languages. The Miami Herald publishes a Spanish language edition. In certain neighborhoods municipal signs such as "No Parking", "No Stopping", "Firelane", or "No Smoking" are in Spanish.

Due to the purchasing power of the Cubans, no merchant, large or small, can afford to be without Spanish-speaking personnel. It is nothing out of the ordinary to be automatically addressed in Spanish by sales clerks. The classified section of the newspapers indicate that there are countless job openings for bi-lingual individuals. The word bi-lingual in Miami does not mean two languages. It means Spanish. The employment opportunities are drastically reduced for the monolingual applicant.

It is interesting to note that many adults are returning to the classroom to learn Spanish. Students in school do not have to be motivated to enroll in Spanish. There is little concern about credithour requirements. The reality of the situation has taught them that communication skills are necessary.

After spending some time in Miami one realizes that this beautiful city in the sun is a living language laboratory. One learns Spanish simply by being there. This method resembles most closely the way we learned our mother tongue. It is certainly less oppressive and more successful than trying to memorize ten irregular verbs per day.

It is obvious that the Spanish language opportunities available in Miami cannot be duplicated in Michigan, Ohio, or Indiana. Classroom teachers with the aid of the electronic language laboratory do the best possible job under the circumstances. The fact that the language 
student spends the entire day, with the exception of the hour devoted to the study of the foreign language, in the English-speaking world, is of course not conducive to his fluency in the foreign tongue. Taking Spanish language students to Miami over Spring break would do wonders for the Spanish program at any school and it is also the least expensive way of placing the students into a native setting.

\section{NAYLDOrnal}

SPECIAL NOTICE

Although regular membership in NALLD is reserved for Laboratory Directors and those directly in charge of laboratories, an associate membership has been created to allow commercial interest to obtain the privileges of membership, exclusive of the right to vote. The privileges of Associate Membership are as follows:

1. Subscription to the NALLD Journal

2. Notices of national and regional meetings

3. Use of the Publications Center

4. Access to Mailing Lists

Associate Membership is $\$ 50.00$ per year.

Associate Membership is given as a FREE BONUS to advertisers taking four consecutive full page ads in the NALLD Journal.

To receive a sample copy of the NALLD Journal please fill in your name and address and send this slip to: Editor, NALLD Journal, Ellis Hall - Ohio University, Athens, Ohio 45701. 